\title{
A Case Series of Guillain-Barré Syndrome After COVID-19 Infection in New York
}

\author{
Monica Chan, MD, Steve C. Han, MD, Sean Kelly, MD PhD, Michael Tamimi, MD, Brandon Giglio, MD, and \\ Ariane Lewis, MD
}

Neurology: Clinical Practice August 2021 vol. 11 no. 4 e576-e578 doi:10.1212/CPJ.0000000000000880

\author{
Correspondence \\ Dr. Chan \\ monica.chan@ \\ nyulangone.org
}

Although much is known about the respiratory complications of infection with severe acute respiratory syndrome coronavirus 2 (SARS-CoV-2), a wider spectrum of neurologic manifestations are beginning to be observed. ${ }^{1}$ We report 2 patients who presented to our hospital in New York, an epicenter of the coronavirus disease 2019 (COVID-19) pandemic, with Guillain-Barré syndrome (GBS) after SARS-CoV-2 infection.

\section{PRACTICAL IMPLICATIONS}

It is important to be aware that patients with COVID-19 can develop Guillain-Barré syndrome.

\section{Case 1}

A 68-year-old man presented with 5 days of progressive gait disturbance and paresthesias of his hands and feet. Eighteen days before the onset of these symptoms, he had a fever and upper respiratory symptoms that lasted 10 days. A nasopharyngeal swab was positive for SARS-CoV-2 infection. Initial examination was notable for $4+/ 5$ weakness in hip flexors and absent vibratory and proprioceptive sense at the toes. Reflexes were $2+$ in the arms and absent in the legs. His gait was unsteady with inability to toe or heel walk. MRI of the lumbosacral spine was unremarkable. He declined lumbar puncture and opted to be monitored conservatively without treatment. Three days after admission, he developed bilateral facial weakness, dysphagia, dysarthria, neck flexion weakness, and inability to ambulate. At this time, he consented to a lumbar puncture; his CSF results were consistent with GBS (table). He completed 5 sessions of plasmapheresis without further symptom progression. Serum ganglioside antibody testing was unremarkable. Electromyography (EMG) was deferred because of infection control measures. His examination stabilized, and he was discharged to a rehabilitation facility after the completion of therapy. His dysphagia has resolved, and 28 days after GBS symptom onset, he can now ambulate with minimal assistance.

\section{Case 2}

An 84-year-old man presented with 7 days of paresthesias of his hands and feet and 3 days of progressive gait disturbance. Twenty-three days earlier, he had a fever, and a nasopharyngeal swab was positive for SARS-CoV-2 infection. Initial examination revealed 3/5 shoulder shrug, 4-/5 hip and neck flexion, and diminished vibration and proprioception at the toes. Reflexes were $1+$ in the arms and absent in the legs. He was unable to stand or ambulate independently. The CSF results were consistent with GBS (table). Thus, plasmapheresis was initiated. Despite treatment, by hospital day 3 , he developed bilateral facial weakness, progressive arm weakness, autonomic dysfunction, and neuromuscular respiratory failure requiring mechanical ventilation. He completed 5 sessions of plasmapheresis without further progression but remained ventilator-dependent, so he was then
MORE ONLINE

COVID-19 Resources

For the latest articles, invited commentaries, and blogs from physicians around the world NPub.org/COVID19 


\begin{tabular}{lllll}
\hline & WBC $\left(\right.$ cells $\left./ \mathrm{mm}^{3}\right)$ & Protein $(\mathrm{mg} / \mathrm{dL})$ & Glucose $(\mathrm{mg} / \mathrm{dL})$ & COVID-19 PCR $(\mathrm{CSF})$ \\
\hline Case 1 & 3 & 226 & 56 & Negative \\
\hline Case 2 & 1 & 67 & 58 & Negative \\
\hline
\end{tabular}

Abbreviations: COVID-19 = coronavirus disease 2019; WBC = white blood cells.

given intravenous immunoglobulin (IVIg). Serum ganglioside antibody testing showed elevated GM2 IgG/IgM antibodies. EMG was deferred. He underwent tracheostomy, and 25 days after GBS symptom onset, he remains quadriparetic with intermittent autonomic dysfunction but is slowly being weaned from the ventilator.

\section{Discussion}

These cases add to the existing literature on GBS associated with COVID-19. ${ }^{2-5}$

The first report of GBS and SARS-CoV-2 is from China; the patient presented with concomitant neurologic and viral symptoms. ${ }^{3}$ In subsequent reports from Italy, Iran, and Pennsylvania, 7 patients developed GBS symptoms less than 2 weeks after the onset of respiratory symptoms. ${ }^{2,4,5}$ In our cases, both patients did not develop GBS symptoms until 3 weeks after the initial onset of viral symptoms. For GBS associated with a preceding infection (respiratory or gastrointestinal), the time interval between infection and onset of neurologic symptoms varies, ranging from 3 days to 3 weeks. ${ }^{6}$ We speculate that our patients' onset of GBS was protracted because of an immunemediated mechanism as opposed to direct viral-mediated damage. Time is required to produce immunoglobulins to SARS-CoV-2 and allow them to circulate and access the peripheral nervous system. Although the Pennsylvania case is an exception and the number of reports is limited, it is interesting to note that there seems to be a progressive delay between onset of viral symptoms and development of GBS as the pandemic spread from East to West.

GBS can be diagnosed clinically, and although an EMG may be helpful, it is not essential to make this diagnosis ${ }^{6}$; thus, an EMG was not performed for our patients because of the pandemic conditions. The CSF, however, was obtained, as we queried whether these patients had a postinfectious process or a process mediated by ongoing viral infection. CSF analysis in each case demonstrated albuminocytologic dissociation commonly seen in GBS, but SARS-CoV-2 was negative; these findings were similar to the CSF results included in the Italian series. $^{2}$

Although we used plasmapheresis as our first-line intervention for both patients and only administered IVIg after decline despite plasmapheresis, all patients presented in other case reports were initially treated with IVIg. ${ }^{2-5}$ Both therapies are known to accelerate time to recovery in patients with GBS with a symptom duration of under 4 weeks. ${ }^{7}$ However, we chose plasmapheresis as the initial treatment because of the concern that both IVIg and SARS-CoV-2 can increase the risk of hypercoagulability. ${ }^{8}$

SARS-CoV-2 infection can cause GBS. The presentation, diagnostic methodology, and treatment for SARS-CoV-2 induced GBS around the world during the present pandemic seem to vary.

\section{Study Funding}

None.

\section{Disclosure}

All authors report no disclosures. Full disclosure form information provided by the authors is available with the full text of this article at Neurology.org/cp.

\section{Publication History}

Received by Neurology: Clinical Practice April 27, 2020. Accepted in final form May 15, 2020.

Appendix Authors

\begin{tabular}{lll}
\hline Name & Location & Contribution \\
\hline $\begin{array}{l}\text { Monica Chan, } \\
\text { MD }\end{array}$ & $\begin{array}{l}\text { NYU Langone } \\
\text { Medical Center }\end{array}$ & $\begin{array}{l}\text { Treated patient; drafted, revised, } \\
\text { and edited the manuscript }\end{array}$ \\
\hline $\begin{array}{l}\text { Steve C. Han, } \\
\text { MD, MBA }\end{array}$ & $\begin{array}{l}\text { NYU Langone } \\
\text { Medical Center }\end{array}$ & $\begin{array}{l}\text { Treated patient; drafted, revised, } \\
\text { and edited the manuscript }\end{array}$ \\
\hline $\begin{array}{l}\text { Sean Kelly, } \\
\text { MD, PhD }\end{array}$ & NYU Langone & $\begin{array}{l}\text { Treated patient; drafted, revised, } \\
\text { and edited the manuscript }\end{array}$ \\
$\begin{array}{l}\text { Michael } \\
\text { Tamimi, MD }\end{array}$ & NYU Langone & $\begin{array}{l}\text { Treated patient; drafted, revised, } \\
\text { and edited the manuscript }\end{array}$ \\
\hline $\begin{array}{l}\text { Brandon } \\
\text { Giglio, MD }\end{array}$ & $\begin{array}{l}\text { NYU Langone } \\
\text { Medical Center }\end{array}$ & $\begin{array}{l}\text { Treated patient; drafted, revised, } \\
\text { and edited the manuscript }\end{array}$ \\
\hline $\begin{array}{l}\text { Ariane Lewis, } \\
\text { MD }\end{array}$ & $\begin{array}{l}\text { NYU Langone } \\
\text { Medical Center }\end{array}$ & $\begin{array}{l}\text { Drafted, revised, and edited the } \\
\text { manuscript }\end{array}$ \\
\hline
\end{tabular}

\section{References}

1. Mao L, Jin H, Wang M, et al. Neurologic manifestations of hospitalized patients with coronavirus disease 2019 in Wuhan, China. JAMA Neurol Epub 2020 Apr 10.

2. Toscano G, Palmerini F, Ravaglia $S$, et al. Guillain-Barré syndrome associated with SARS-CoV-2. N Engl J Med Epub 2020 Apr 17. 
3. Zhao H, Shen D, Zhou H, Liu J, Chen S. Guillain-Barré syndrome associated with SARS-CoV-2 infection: causality or coincidence? Lancet Neurol 2020;19: 383-384.

4. Virani A, Rabold E, Hanson T, et al. Guillain-Barré Syndrome associated with SARSCoV-2 infection. IDCases 2020;20:e00771.

5. Sedaghat Z, Karimi N. Guillain Barre syndrome associated with COVID-19 infection: a case report. J Clin Neurosci Epub 2020 Apr 15.
6. Yuki N, Hartung HP. Guillain-Barré syndrome. N Engl J Med 2012;366:2294-2304.

7. Hughes RC, Wijdicks EFM, Barohn R, et al. Practice parameter: immunotherapy for Guillain-Barré syndrome: report of the Quality Standards Subcommittee of the American Academy of Neurology. Neurology 2003;61:736-740.

8. Panigada M, Bottino N, Tagliabue P. Hypercoagulability of COVID-19 patients in intensive care unit. A report of thromboelastography findings and other parameters of hemostasis. J Thromb Haemost Epub 2020 Apr 17. 


\section{Neurology ${ }^{\circ}$ Clinical Practice}

A Case Series of Guillain-Barré Syndrome After COVID-19 Infection in New York

Monica Chan, Steve C. Han, Sean Kelly, et al.

Neurol Clin Pract 2021;11;e576-e578 Published Online before print May 21, 2020

DOI 10.1212/CPJ.0000000000000880

This information is current as of May 21, 2020

Updated Information \&

Services

References

Subspecialty Collections

Permissions \& Licensing

Reprints including high resolution figures, can be found at:

http://cp.neurology.org/content/11/4/e576.full.html

This article cites 4 articles, 1 of which you can access for free at: http://cp.neurology.org/content/11/4/e576.full.html\#\#ref-list-1

This article, along with others on similar topics, appears in the following collection(s):

All Clinical Neurology

http://cp.neurology.org//cgi/collection/all_clinical_neurology

All Neuromuscular Disease

http://cp.neurology.org//cgi/collection/all_neuromuscular_disease COVID-19

http://cp.neurology.org//cgi/collection/covid_19

Guillain-Barre syndrome

http://cp.neurology.org//cgi/collection/guillainbarre_syndrome

Post-infectious

http://cp.neurology.org//cgi/collection/postinfectious_

Information about reproducing this article in parts (figures,tables) or in its entirety can be found online at:

http://cp.neurology.org/misc/about.xhtml\#permissions

Information about ordering reprints can be found online: http://cp.neurology.org/misc/addir.xhtml\#reprintsus

Neurol Clin Pract is an official journal of the American Academy of Neurology. Published continuously since 2011, it is now a bimonthly with 6 issues per year. Copyright (C) 2020 American Academy of Neurology. All rights reserved. Print ISSN: 2163-0402. Online ISSN: 2163-0933.

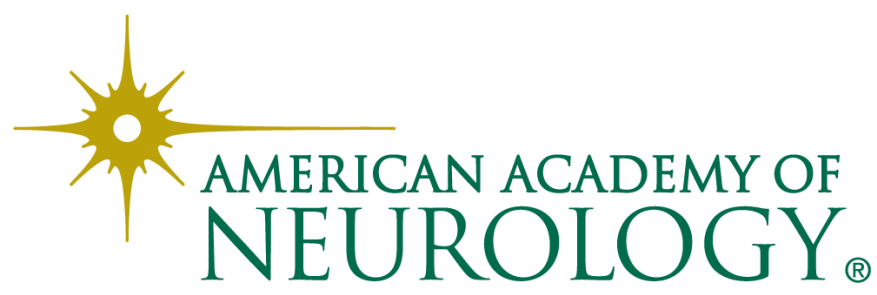

